Portland State University

PDXScholar

$1-2003$

\title{
Avian Population Trends Within the Evolving Agricultural Landscape of the Eastern and Central United States
}

Michael T. Murphy

Portland State University, murphym@pdx.edu

Follow this and additional works at: https://pdxscholar.library.pdx.edu/bio_fac

Part of the Biology Commons, and the Ornithology Commons

Let us know how access to this document benefits you.

\section{Citation Details}

Murphy, Michael T., "Avian Population Trends Within the Evolving Agricultural Landscape of the Eastern and Central United States" (2003). Biology Faculty Publications and Presentations. 70. https://pdxscholar.library.pdx.edu/bio_fac/70

This Article is brought to you for free and open access. It has been accepted for inclusion in Biology Faculty Publications and Presentations by an authorized administrator of PDXScholar. Please contact us if we can make this document more accessible: pdxscholar@pdx.edu. 


\title{
AVIAN POPULATION TRENDS WITHIN THE EVOLVING AGRICULTURAL LANDSCAPE OF EASTERN AND CENTRAL UNITED STATES
}

\author{
Michael T. Murphy ${ }^{1}$ \\ Department of Biology, P.O. Box 751, Portland State University, Portland, Oregon 97207, USA
}

\begin{abstract}
State-level Breeding Bird Survey (1980-1998) and U.S. Department of Agriculture statistics were used to test the hypothesis that changes in agricultural land use within the eastern and central U.S. have driven population trends of grassland and shrub habitat birds over the past two decades. The degree to which population trends differed between grassland and shrub habitats was evaluated with respect to migratory and nesting behavior. Grassland birds declined significantly between 1980 and 1999, but, on average, shrub habitat species did not. Grassland-breeding, long-distance migrants exhibited the strongest negative trends. Most species $(78 \% ; n=63)$ exhibited at least one significant association between population trends and changes in agricultural land use, and in most, land use "explained" $25-30 \%$ of the variation in population trends among states. Changes in the farmland landscape accounted for more of the interstate variability of population trends of short-distance migrants than of both long-distance migrants and residents, and that variability was greater in grassland than shrub species. Declines in the area of rangeland and cover crops were followed by population declines and increases, respectively, by many species. Increases of land in the Conservation Reserve Program had negative associations with population trends of some shrub species. The results indicate that grassland birds have declined strongly over the past two decades, and that regardless of migratory behavior or nesting habits, avian population trends are linked strongly to changes in agricultural land use within North America. Received 26 February 2002, accepted 22 October 2002.
\end{abstract}

RESUMEN.-Se utilizaron censos de aves reproductivas a nivel estatal (1980-1998) y estadísticas del Departamento de Agricultura de los Estados Unidos para poner a prueba la hipótesis de que los cambios en el uso de las tierras agrícolas del este y centro del país han afectado las tendencias poblacionales de las aves de pastizal y de vegetación arbustiva a través de las últimas dos décadas. Se evaluó el nivel al que las tendencias poblacionales difirieron entre los hábitats de pastizal y vegetación arbustiva con relación al comportamiento migratorio y de anidación. Las aves de pastizal declinaron significativamente entre 1980 y 1999, pero en promedio, las especies de hábitats arbustivos no. Las especies migratorias de larga distancia que se reproducen en pastizales presentaron las tendencias poblacionales negativas más fuertes. La mayoría de las especies $(78 \% ; n=63)$ mostraron al menos una asociación significativa entre sus tendencias poblacionales y los cambios en el uso de las tierras agrícolas, y en la mayoría, el uso de la tierra «explicó» entre el 25 y el $30 \%$ de la variación en las tendencias poblacionales entre estados. Los cambios en el paisaje agrícola fueron responsables por una mayor parte de la variabilidad interestatal de las tendencias poblacionales de aves migratorias de corta distancia que de la de las migratorias de larga distancia y las residentes. Esta variabilidad fue mayor en las especies de pastizal que en las de zonas arbustivas. Las disminuciones en el área de campos de pastoreo y de cultivos fueron seguidas, respectivamente, por disminuciones e incrementos poblacionales de muchas especies. Los incrementos del área incluida en el programa de reservas de conservación presentaron asociaciones negativas con las tendencias poblacionales de algunas especies de zonas arbustivas. Los resultados indican que las aves de pastizal han disminuido ostensiblemente durante las dos últimas décadas, y que independientemente de su comportamiento migratorio o sus hábitos de anidación, las tendencias poblacionales de las aves están estrechamente ligadas a los cambios en el uso de las tierras agrícolas dentro de Norte América.

POPUlations OF MANY grass- and shrubland breeding birds have declined in recent decades

${ }^{1}$ E-mail: murphym@pdx.edu in apparent response to the loss of small farms, declines of shrub habitat, and expansion of "industrial agriculture" (Askins 1993, 1999, 2000, 2001; O'Connor and Boone 1992; Hagan 1993; Knopf 1994; Warner 1994; Johnson and Igl 1995; 
Peterjohn and Sauer 1999; Vickery et al. 1999). Agriculture encompasses up to $50 \%$ of the land area within portions of the United States (U.S. Department of Agriculture 1998) and its effect on the landscape will always be large. Thus, the identification of agricultural practices and farmland (i.e. landscape) structures that support both birds and farm operators is important for maintenance of a diverse farmland avifauna (Musters et al. 2000). Agricultural practices represent decisions about choice of crops, pesticides, fertilizers, and field maintenance (Basore et al. 1986, Dale et al. 1997), whereas farmland structure refers to relative abundance and distribution of crops, pasture, and uncropped areas (Rodenhouse et al. 1995).

Although the decline of grass- and shrubland birds is seemingly well established, few studies have been able to directly link agriculture practices with changes in bird populations. A strong case has been made for the adverse effects of early and frequent cutting of hay and frequent tilling of crops on avian productivity (Rodenhouse and Best 1983, Bollinger et al. 1990, Herkert 1997), population size, and community structure (Frawley and Best 1991, Dale et al. 1997). Less is known about the effect of changes in farmland structure on birds, but the U.S. Conservation Reserve Program (CRP; Reynolds et al. 1994, Johnson and Igl 1995, Best et al. 1997) and Canada's Permanent Cover Program (PCP; McMaster and Davis 2001) appear to have benefited grassland birds by increasing the relative amount of unharvested land. Population declines of Bobolinks (Dolichonyx oryzivorus; Herkert 1997) have also been linked to habitat loss over large geographic areas. Beyond those studies, however, few attempts have been made to measure the effect of changes in relative abundance of croplands and unharvested areas on bird populations and much remains to be learned of the effect of the evolving agricultural landscape on birds.

In this report I use U.S. Fish and Wildlife Service Breeding Bird Survey (BBS) and U.S. Department of Agriculture (USDA) statistics to test for associations between changes in farmland structure and population trends of birds breeding in grassland and early successional habitats (i.e. shrub and edge; hereafter "shrub") of the agricultural landscape of the eastern and central United States. On the basis of previous research (see above), I expected that both grassland and shrub species would exhibit negative population trends, but that declines would be more severe and widespread among grassland species because open grassland habitats (pasture, rangeland) have declined more rapidly than farm woods (and presumably shrub and edge) in recent years (Table 1). Following the same logic, I further predicted that states with the greatest loss of grasslands would exhibit the severest declines of grassland birds. The latter expectation is particularly germane to debates over whether migratory bird populations are limited primarily by habitat availability during the breeding or nonbreeding season (Rappole and MacDonald 1994, 1998; Sherry and Holmes

TABLE 1. Description and statistics for the agricultural commodities and land-use variables (U.S. Department of Agriculture 1998) that were used in the analyses of interstate variation in population trends of breeding birds.

\begin{tabular}{|c|c|c|c|}
\hline Variable & Description & 1997 Mean (SD)a & $\begin{array}{c}\text { Trend } \\
(1987-1997)^{a}\end{array}$ \\
\hline Cattle & Total number of cattle raised in state & $7.5 \times 10^{5}\left(9.6 \times 10^{5}\right)$ & $+0.94(1.53)^{*}$ \\
\hline Dairy cows & Total number of cows in production & $1.7 \times 10^{5}\left(2.5 \times 10^{5}\right)$ & $-3.37(2.16)^{*}$ \\
\hline Cover crops (ha) & $\begin{array}{l}\text { Land in cover crops (legumes and soil improvement grasses) } \\
\text { that were not harvested or pastured }\end{array}$ & $3.0 \times 10^{5}\left(4.1 \times 10^{5}\right)$ & $-2.79(3.29)^{*}$ \\
\hline CRP land (ha) & Land enrolled in the Conservation Reserve Program & $6.6 \times 10^{5}\left(8.7 \times 10^{5}\right)$ & $+4.15(4.10)^{*}$ \\
\hline Hayfields (ha) & $\begin{array}{l}\text { Cropland harvested as alfalfa, small tame grasses, } \\
\text { wild grasses, silage, green chop }\end{array}$ & $1.4 \times 10^{6}\left(1.2 \times 10^{5}\right)$ & $+0.46(1.52)$ \\
\hline Pastureland (ha) & Cropland used only for pasture or grazing & $1.5 \times 10^{6}\left(2.1 \times 10^{6}\right)$ & $-0.71(1.62)^{*}$ \\
\hline Rangeland (ha) & Pasture and rangeland, other than that included as pure pasture & $7.1 \times 10^{6}\left(1.6 \times 10^{6}\right)$ & $-1.00(1.20)^{*}$ \\
\hline Harvested crops (ha) & All harvested land other than hayfields (above) & $5.7 \times 10^{6}\left(6.4 \times 10^{6}\right)$ & $+0.59(1.13)^{*}$ \\
\hline Farm woods (ha) & $\begin{array}{l}\text { Natural or planted woodlots or timber tracts, cut-over and } \\
\text { deforested land with young second growth, and pastured woodland. }\end{array}$ & $1.6 \times 10^{6}\left(1.3 \times 10^{6}\right)$ & $-0.56(0.94)^{*}$ \\
\hline
\end{tabular}


1995; Latta and Baltz 1997). If losses of breeding habitat underlie population declines, then residents and migrants (which winter in many locations) should respond similarly to changes in breeding habitat availability.

Interspecific comparisons of avian population trends and changes in land use are complicated, however, by the fact that migratory patterns and nesting habits are not distributed uniformly across habitats. Most grassland birds build open-cup nests, place them on (or near) the ground, and migrate short distances to winter within agricultural landscapes of the southern United States or northern Mexico (Ig1 and Johnson 1997, Vickery et al. 1999). Longdistance migrants spend nearly half the year away from North America, and most build open-cup nests in trees. Residents are also more common in shrub habitats than grasslands, and residents more often nest in protected cavities that suffer lower rates of nest loss to predators (Martin 1995). I therefore test for a direct role of changes in farmland habitat availability on avian population trends, but attempt to test for possible confounding influences associated with migratory and nesting behavior.

\section{MethodS}

Avian population trends.-Analyses were limited to species that do not depend on aquatic habitats (e.g. all Anseriformes) or closed forests for nesting. State-level population trend estimates (1980-1999) were obtained from the BBS for the 40 states located at least partially east of the Rocky Mountains (see Acknowledgments). I focused on the last 20 years because that postdates the severe weather of the late 1970s that Sauer et al. (1996) showed had a negative effect on many eastern North American species. Breeding Bird Survey data are generated from roadside surveys that are conducted during the peak of the breeding season. Surveys have been conducted in a standard manner since 1966, and $>2,800$ routes have been surveyed annually since 1980 (Peterjohn and Sauer 1999). Each route is $39.4 \mathrm{~km}$ long, and observers stop every $0.8 \mathrm{~km}$ to record all birds heard or seen within $0.4 \mathrm{~km}$ of the observer during the 3 min census period (see Robbins et al. 1986). The linear route-regression approach was used to estimate population trend (Geissler and Sauer 1990), which are reported as a percentage change per year.

Agricultural land use.-The USDA conducts censuses of agricultural land use and commodities every five years using mailout-mailback questionnaires. The 1997 census was based on over 2 million census forms with a return rate of at least $75 \%$ for all coun- ties within the United States (U.S. Department of Agriculture 1998). Farm operators report livestock numbers, and total area of harvested lands, harvested hayfields, individual row crops, orchards, woodland, and agricultural set-asides (e.g. CRP land). Other statistics are also reported, but to reduce the probability of generating spurious results statistics for only nine agricultural landscape and commodity variables were used that published research and personal experience suggested might potentially influence avian numbers (Table 1). A single variable described the total area of harvested crops (e.g. corn, oats, wheat, orchards, and various vegetables, but no hay or cover crops), a second summarized the total area of farm woods, two variables described livestock numbers, and four variables described open spaces that were or were not actively grazed or harvested. Two of the four open-space variables were used for pasture, grazing, or both. The first, pastureland, was classified by the USDA as cropland, whereas the second, rangeland, was not. The former is more regularly and more heavily grazed than the latter. The ninth variable was area of CRP land. The CRP began in 1985 (Johnson and Igl 1995) and for that reason and the fact that the USDA summaries did not report all statistics back to 1982, analyses of landscape changes are limited to farm census data that have been available since the inception of the CRP program (1987 to 1997). For each state included in the analysis, a percentage change for all nine variables over the 10-year period was calculated as ([([1997 value - 1987 value $] / 1987$ value $) / 10]$ years $)$ $\times$ 100). In limiting analyses to landscape changes between 1987 and 1997, I made the assumption that patterns of land use reported were representative of ongoing changes between 1980 and 1997. Comparison of rates of change between 1982 and 1997 with rates of change between 1987 and 1997 for the four variables for which data were available in 1982 support that assumption (harvested land, $r=0.701$; number of beef, $r$ $=0.800$; number of cows, $r=0.884$; hayfields, $r=0.921$; $P<0.0000$ for all four).

Statistical analyses.-Reliability of BBS data are reduced by low sample size (i.e. few routes), low species abundance, observer effects, or missing years. An attempt was made to eliminate unreliable data using a three-step process. First, the BBS has its own "credibility measures" to identify trend estimates that are of low (having important deficiencies), medium (having few deficiencies), or high quality (lacking any noteworthy deficiencies). As a compromise between having sufficient data for analyses and maintaining quality, states that the BBS characterized as being of low quality were omitted. Second, for each species state trend estimates that were more than three standard deviations [SD] outside the species' mean trend were omitted. Third, preliminary stepwise multiple regressions (STATISTIX; Analytical Software, Tallahassee, Florida) were conducted for each species to identify 
possible correlates of population trends at the level of state. The dependent variable in all analyses was the state-level population trend, and predictor variables were the nine farmland landscape variables for each state, plus "region". Region was included as a dummy variable to distinguish between the eastern and central regions (all states east of the Mississippi River [value =0], and between the Mississippi River and Rocky Mountains [= 1], respectively). An F-to-enter and $F$-to-remove of $P<0.1$ was used to minimize the chance of making Type II errors (i.e. acceptance of false null hypothesis of no relationship between variables). All independent variables that entered the regression were examined visually to ensure that statistically significant relationships were not the result of single points, and that significant relationships persisted when suspect points were eliminated. Similarly, when no independent variables entered the regression, suggestive relationships were visually examined (i.e. correlations for which $0.1<P \approx 0.2$ ) to be certain that single, unusual points did not obscure significant relationships.

The habitat and geographic restrictions and data filtering resulted in the retention of 63 species for analyses of the relationship between state-level population trends and farmland structure. All species were classified into one of two breeding habitats, one of three migratory behaviors, and one of three nest types. Species were classified as breeding in either grassland (both obligatory and facultative; see Vickery et al. 1999) or shrub habitats. Classifying species to discrete habitat is difficult because nearly all species use a range of habitats and researchers have different experiences. A variety of sources were therefore used to identify a primary breeding habitat, including Ehrlich et al. (1988), DeGraaf and Rappole (1995), Vickery et al. (1999), Hunter et al. (2001), numerous Birds of North America accounts, and my research experiences in Kansas, Indiana, and New York. I used personal experience to make a final decision when opinions on habitat use differed. For instance, Vickery et al. (1999) classified American Kestrels (see Appendix for scientific names), Eastern Kingbirds, and Loggerhead Shrikes as facultative grassland species, but Hunter et al. (2001) characterized them as using "disturbancemaintained woodlands." My experience with all three is much closer to the former, and therefore I used Vickery et al.'s (1999) classification. All swallows (Hirundinidae) are aerial foragers that capture prey over open (grassland, aquatic) habitats. Their nesting habits, however, make them either directly dependent (Purple Martins and Barn Swallows) or independent (Cliff, Bank, and Rough-winged swallows) of human structures. Given their unique foraging and nesting requirements, swallows were treated separately in analyses. Tree Swallows were the only exception. They were classified as a shrub species because they nest in abandoned tree cavities near forest edges and beaver ponds (Robertson et al. 1992).
The categorization of species as residents (breeding and wintering range virtually identical), shortdistance migrants (southward shift of population in winter, but maintenance of populations to at least northern Mexico), or long-distance migrants (complete separation of breeding and winter range, and winter distribution well south of northern Mexico) was based on range maps for each species (BNAM accounts; DeGraaf and Rappole 1995). Nest type varied from open-cup to cavity- and niche-nesters. Cavity- and niche-nesters (e.g. Eastern Phoebe, Barn Swallow) were combined, but a distinction was made between them and two classes of open-cup nesters: ground- or near-ground ( $\leq 1 \mathrm{~m}$ of ground), and those that nest above ground $(>1 \mathrm{~m})$ in shrubs or trees. The brood-parasitic Brown-headed Cowbird was treated separately. Habitat, migratory and nesting classifications, and BBS population-trend estimates for the combined eastern and central regions are given in the Appendix.

Population trends for all species from the combined eastern and central United States were compared between habitats and among migratory and nesting classes using general linear models two-way analyses of variance (ANOVA; STATVIEW [SAS Institute 1999]). Small sample sizes precluded threeway designs. Statistics are reported as untransformed mean \pm standard deviation (SD). Stepwise multiple regression was also used to test for relationships between intraspecific differences in population trends and changes in farmland structure among states. Tests of the significance of all variables in the regressions were based on Type III sums of squares, and the $R^{2}$ values reported are adjusted for the number of independent variables.

Significant correlations existed among roughly a third of the landscape variables (Table 2). The numerous correlations prompted me to initially use principal components analysis (PCA) to search for one to two composite axes that summarized the major patterns of change in the farmland landscape. However, I opted against the use of the PCA-generated axes in the multiple regressions because of the difficulty of establishing associations between bird population trends and specific landscape variables. I nonetheless acknowledge that my analyses are correlational, and that the variables generated from the USDA summaries may correlate with other ongoing changes in the landscape (e.g. urban sprawl, secondary succession of forests) that are ultimately responsible for changes in bird numbers.

The coefficient of determination $\left(R^{2}\right)$ from stepwise regressions, a variable that I refer to as the "explained variation," was compared among habitat, and migratory and nesting classes using one-way and twoway ANOVA (as above) to test the hypothesis that grassland birds would show the strongest associations between population trends and changes in the landscape. $R^{2}$ values were arcsine transformed, and 
TABLE 2. Correlation matrix describing the relationships among the farmland landscape variables used in the analyses of the relationships between bird population trends and changes in land use (1987-1997) in the eastern and central United States ( $n=40$ states).

\begin{tabular}{lcccccccc}
\hline \hline Land use & Cattle & $\begin{array}{c}\text { Cover } \\
\text { crops }\end{array}$ & Cows & CRP & Pasture & Range & $\begin{array}{c}\text { Farm } \\
\text { woods }\end{array}$ & $\begin{array}{l}\text { Hay- } \\
\text { fields }\end{array}$ \\
\hline Cover crops & 0.110 & & & & & & & \\
Cows & 0.137 & -0.074 & & & & & & \\
CRP land & -0.079 & -0.141 & -0.240 & & & & & \\
Pastureland & $0.372^{\mathrm{a}}$ & $0.433^{\mathrm{b}}$ & -0.157 & -0.252 & & & & \\
Rangeland & $0.458^{\mathrm{b}}$ & 0.167 & 0.008 & -0.120 & $0.369^{\mathrm{a}}$ & & & \\
Farm woods & -0.059 & 0.272 & -0.082 & -0.017 & -0.202 & -0.045 & & \\
Hayfields & $0.312^{\mathrm{a}}$ & $0.498^{\mathrm{c}}$ & -0.068 & -0.232 & $0.633^{\mathrm{c}}$ & $0.326^{\mathrm{a}}$ & $0.316^{\mathrm{a}}$ & \\
Harvested crops & 0.092 & -0.208 & $0.350^{\mathrm{a}}$ & -0.006 & -0.238 & 0.215 & -0.261 & -0.214 \\
\hline $\mathrm{a} P<0.05$. & & & & & & & & \\
$\mathrm{b} P<0.01$. & & & & & & & &
\end{tabular}

then subjected to a logarithmic transformation (after adding 1 ) to yield data that conformed to the standard assumptions of ANOVA. Given the arbitrariness of using an $\alpha$ of 0.05 to establish statistical significance (Johnson 1999) and my desire to minimize the chances of making Type II errors (Steidl et al. 1997), a $P \leq 0.10$ was used to establish statistical significance and to calculate confidence intervals, but I report all exact $P$ values except when $P<0.001$ (reported as $P=0.000$ ).

\section{Results}

Landscape composition and change.-Rangeland and cropland (other than hayfields) constituted $70 \%$ of the agricultural lands in the eastern and central states. In total, cover crops ( $1.6 \%$ of total) and CRP fields (3.6\% of total) covered only $5 \%$ of the farmland landscape (Table 1), whereas hayfields, pasturelands, and farm woods all encompassed $\sim 8 \%$ of the area.

Substantial changes occurred in the landscape between 1987 and 1997. The number of cows declined, but cattle increased. And although the area of CRP lands showed a large increase (Table 1), farm woods and 3 of 4 open space variables (cover crops, pastureland, and rangeland) exhibited declines (Table 1). The loss in area of those lands was accounted for, presumably at least in part, by an increase in the area of harvested crops (Table 1). Ten of the 36 possible pairwise comparisons yielded significant correlated changes (Table 2). The strongest relationships involved positive correlations among hayfields, pasturelands, and cover crops. In other words, states that saw an increase in one of those land uses often exhibited growth in the others as well. With one exception, most of the remaining significant $(P<0.05)$ correlations were of substantially lower magnitude $(r \leq 0.372)$. The one exception (rangeland and cattle) was the result of a single point, that when excluded, resulted in a weaker (but still significant) relationship between cattle and rangeland $(r=0.331, P=0.023)$.

Population trends.-Population trends for all species (except swallows) averaged -0.61 $\left( \pm 1.74 \%\right.$ year $^{-1}, 90 \% \mathrm{CI}=-1.00$ to $\left.-0.23, n=58\right)$. Of the three two-way combinations of habitat, migration, and nest type (Table 3), habitat and migration accounted for the largest share of the variation in population trends $\left(R^{2}=20.2\right.$ vs. $13.3 \%$ for habitat-nest type and $12.7 \%$ for migration-nest type). The significance of the habitat and migration model was due solely to the effects of habitat $(P=0.006)$, with grassland species $\left(-1.08 \pm 1.79 \%\right.$ year $^{-1}, 90 \% \mathrm{CI}=-1.69$ to -0.47 ) exhibiting stronger negative population trends than shrub species $\left(-0.26 \pm 1.67 \%\right.$ year $^{-1}$, $90 \% \mathrm{CI}=-0.75$ to 0.22 ). The interaction between habitat and migration was marginally significant, but neither of the interaction terms in the other two models approached significance (Table 3).

The marginally significant interaction term in the two-way comparison of habitat and migration prompted separate analysis of population trends of grassland and shrub species. Among the latter, short- and long-distance migrants tended to remain stable or decline whereas residents increased $(F=3.692, \mathrm{df}=2$ and $29, P$ $=0.037$; Fig. 1). Grassland species, on the other hand, showed negative population trends within all three migrant categories $(F=0.376, \mathrm{df}=2$ and 22, $P=0.376$; Fig. 1). Grassland-breeding, 
TABLE 3. Results of two-way analyses of variance of BBS population trends for bird species breeding in agricultural landscapes in states within the eastern and central regions of the United States. Independent variables were breeding habitat, migratory behavior, and nest type.

\begin{tabular}{lccc}
\hline \hline Variable & $F$ & $\mathrm{df}$ & $P$ \\
\hline Habitat & 8.251 & 1 and 52 & 0.006 \\
Migration & 1.419 & 2 and 52 & 0.251 \\
Habitat $\times$ migration & 2.424 & 2 and 52 & 0.099 \\
Habitat & 0.077 & 1 and 51 & 0.782 \\
Nest type & 1.273 & 2 and 51 & 0.289 \\
Habitat $\times$ nest type & 1.520 & 2 and 51 & 0.228 \\
Migration & 0.727 & 2 and 48 & 0.489 \\
Nest type & 3.043 & 2 and 48 & 0.057 \\
Migration $\times$ nest type & 1.045 & 2 and 48 & 0.394 \\
\hline
\end{tabular}

long-distance migrants exhibited the sharpest declines $\left(-1.83 \pm 1.50 \%\right.$ year $^{-1}, 95 \%$ CI $=-3.06$ to -0.59 ; Fig. 1), as did swallows $(-1.50 \pm 1.87 \%$ year $^{-1}, 95 \%$ CI $=-3.29$ to 0.29 ; Fig. 1 ), another group of long-distance migrants that regularly forage over grasslands.

Population trends and farmland structure.-Of the 63 species, 49 (77.8\%) exhibited at least one statistically significant relationship between population trends and changes in farmland structure when comparisons were made among states. Nearly $25 \%(24.6 \pm 21.1 \%, 90 \%$ CI $=20.1$ to 29.1) of variation in population trends of the 63 species could be accounted for by the landscape variables, a value that increased to $31.6 \%$ $( \pm 19.4 \%, 95 \% \mathrm{CI}=27.0$ to 36.2$)$ when the mean was based on the 49 species with significant regressions. For seven species, $>50 \%$ of the variability in the state-level BBS trend estimates was associated with changes in agricultural land use.

Data for all species are summarized in the Appendix, but results are described for three species to give insight into the analyses. Bobolink trends were positively associated with an increase in the area of hayfields (Fig. 2A; $P=$ $0.004)$, and negatively associated with increase in area of pasturelands $(P=0.010)$. Population trends also tended to be more positive in the central compared to the eastern states $(P=0.07)$. The positive association with hayfields is consistent with known habitat preferences (Bollinger et al. 1990, Herkert 1997), and the three variables accounted for $\left(R^{2}\right) 39.5 \%$ of the interstate variation in Bobolink population trends $(P=0.007 ; n$

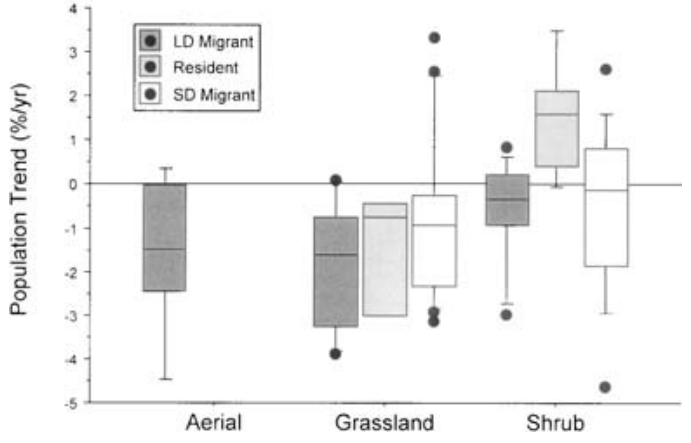

FIG. 1. Comparisons of avian population trends by habitat and migratory behavior. Aerial, grassland, and shrub refer to aerial foraging swallows, grassland species, and shrub species, respectively. Median values indicated by horizontal line within the box, which encompasses the 25th to the 75th percentiles of observations. Vertical lines mark the 10th and 90th percentiles, and individual points indicate observations that lie outside the 10th and 90th percentiles.

$=22$ states). Vesper Sparrow population trends were associated negatively with increases in the area of CRP land (Fig. 2B; $R^{2}=43.3 \%, n=21$ states, $P=0.000$ ), a result that is consistent with their regular use of low density native vegetation and rowcrop fields (Rodenhouse and Best 1983, Johnson and Igl 1995, Patterson and Best 1996). House Wren population trends were very strongly and positively related to increases in area of pasturelands (Fig. 2C; $P=0.000$ ). House Wren trends were also negatively associated with area of both CRP fields $(P=0.010)$ and cover crops $(P=0.044)$, but were positively associated with increases in area of rangeland $(P=$ $0.016 ; R^{2}$ of the four variable model $=73.5 \%, P=$ $0.000, n=31$ ).

Results for all species were used to examine the degree to which the explained variation $\left(R^{2}\right)$ of different species varied with habitat, nesting biology, and migration behavior. Of the three two-way combinations, $R^{2}$ values were most closely associated with differences in migratory behavior and habitat (Table 4 ). The mean $R^{2}$ of the short-distance migrants $(32.1 \pm 22.4 \%, n=$ 29) was higher than that of both long-distance migrants $(19.3 \pm 19.8 \%, n=21)$ and residents (13.2 $\pm 13.9 \%, n=8$; Fig. 3). Grassland species also had higher $R^{2}$ values $(30.4 \pm 18.7 \%, n=25)$ than shrub species $(20.7 \pm 22.9 \%, n=33$; Fig.3). All interaction terms were nonsignificant. The $R^{2}$ of swallows (excluding the Tree Swallow) 

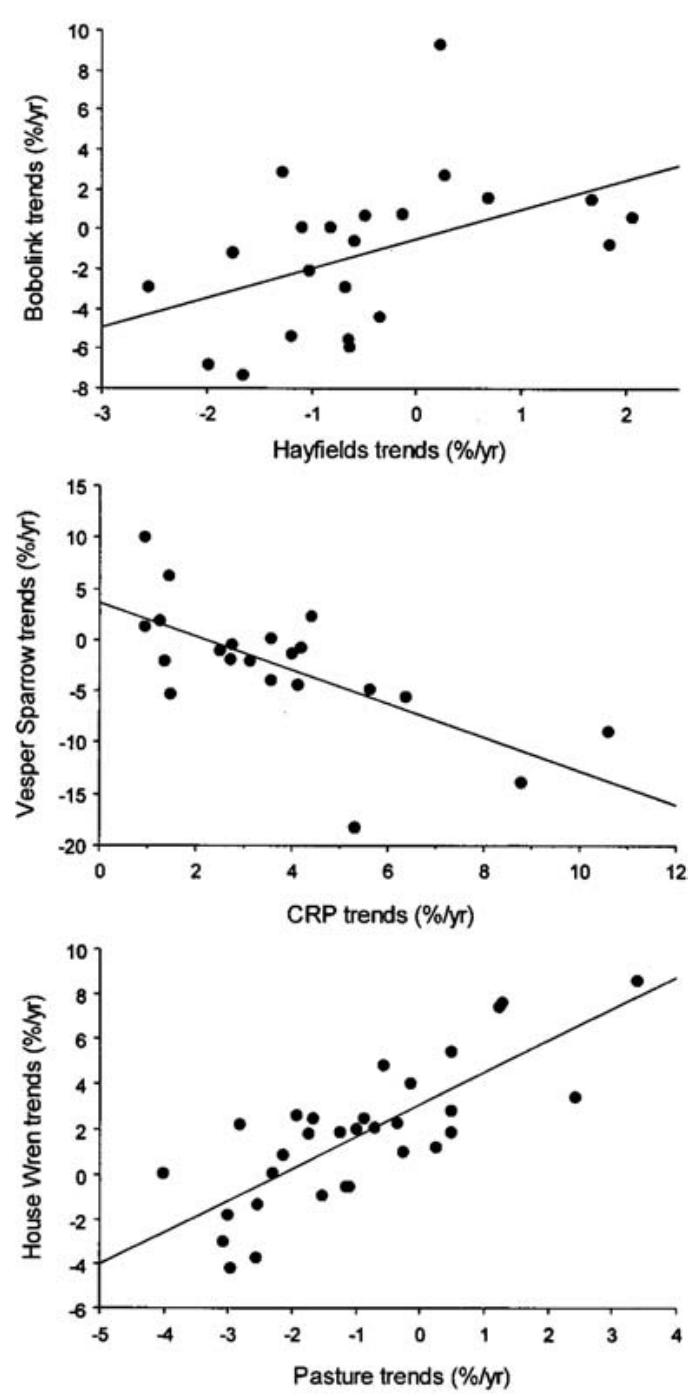

FIG. 2. Three examples of the analyses of interstate variation in population trends. Correlation coefficients between Bobolink population trends and changes in hayfields $(r=0.460, n=22, P=0.031)$, Vesper Sparrow trends and changes in CRP fields $(r=$ $-0.679, \mathrm{n}=21, P<0.001)$, and House Wren trends and changes in pasture area $(r=0.745, n=31, P<0.001)$ were all significant. The relationship between Vesper Sparrow population trends and CRP area remained significant when the two largest CRP trend estimates were omitted ( $r=-0.596, n=19, P=0.007)$.

averaged $21.8( \pm 21.5 \%, n=5)$, a figure that was close to the average for other long-distance migrants.

Relative importance of individual landscape variables.-Between 25 and $30 \%$ of the variation
TABLE 4. Results of two-way analyses of variance that compared $R^{2}$ values from stepwise multiple regressions relating population trends of birds to changes in the agricultural landscape. The ability of the landscape variables to account for population trends was compared among species of different breeding habitats, and with different migratory and nesting behaviors.

\begin{tabular}{lccc}
\hline Variable & $F$ & df & $P$ \\
\hline Habitat & 3.248 & 1 and 52 & 0.077 \\
Migration & 2.665 & 2 and 52 & 0.079 \\
Habitat $\times$ migration & 1.021 & 2 and 52 & 0.367 \\
Habitat & 0.366 & 1 and 51 & 0.548 \\
Nest type & 0.564 & 2 and 51 & 0.572 \\
Habitat $\times$ nest type & 0.100 & 2 and 51 & 0.905 \\
Migration & 1.923 & 2 and 48 & 0.157 \\
Nest type & 1.110 & 2 and 48 & 0.338 \\
Migration $\times$ nest type & 0.526 & 2 and 48 & 0.717 \\
\hline
\end{tabular}

in population trends of most birds could be associated with changes in farmland structure, but did certain variables emerge repeatedly as useful predictors of population trends? To address that question, I assumed that a habitat variable had a primarily positive relationship with population trends when there were more than twice as many positive as negative correlations (and vice versa). On the basis of that criterion, positive population trends of grassland birds tended to be associated with increases in area of mainly rangeland, but also acres of harvested crops (Table 5). No variable exhibited a clear negative relationship with population trends of grassland birds. Among shrub species, population increases tended to be associated with increases in rangeland, pasturelands, hayfields, and harvested land, whereas declines were associated with increases in area of CRP fields and cover crops (Table 5). No single variable emerged as important for swallows, but all four correlations with variables describing open spaces (pasture, rangeland, and hayfield) were positive (Table 5). Disregarding the primary breeding habitat for the 63 species, changes in area of rangeland and cover crops had the most frequent and consistent associations with population trends. Thirteen of 14 correlations of population trends with rangeland were positive, whereas 9 of 12 correlations of population trends with cover crops were negative (Table 5). Positive population trends also tended to be associated with increases of harvested land, whereas significant associations between 
TABLE 5. A comparison of the number of significant positive $(+)$ and negative $(-)$ correlations between agricultural landscape variables and population trends for the 58 species of birds breeding in either grasslands or shrub habitats from the eastern and central United States. Data for five species of swallows (Hirundinidae) presented separately. Results are summarized ("Total") for analyses that stipulated either an $\alpha$ of $P \leq 0.10, P \leq 0.05$, or $P \leq 0.01$ for the establishment of statistical significance.

\begin{tabular}{|c|c|c|c|c|c|c|c|c|c|c|c|c|}
\hline \multirow[b]{2}{*}{$\begin{array}{l}\text { Landscape } \\
\text { variables }\end{array}$} & \multicolumn{8}{|c|}{$P \leq 0.10$} & \multicolumn{2}{|c|}{$\begin{array}{l}P \leq \\
0.05\end{array}$} & \multicolumn{2}{|c|}{$\begin{array}{l}P \leq \\
0.01\end{array}$} \\
\hline & & $\begin{array}{c}\text { ass } \\
- \\
\end{array}$ & $\begin{array}{l}\text { Sh } \\
+ \\
\end{array}$ & ub & $\begin{array}{l}\text { lo } \\
+ \\
\end{array}$ & $\begin{array}{l}\text { al- } \\
\text { NS } \\
-\end{array}$ & & $\begin{array}{l}\text { tal } \\
- \\
\end{array}$ & $\begin{array}{l}\text { Tc } \\
+ \\
\end{array}$ & $\begin{array}{l}\text { tal } \\
-\end{array}$ & & otal \\
\hline Cover crops & 3 & 5 & 0 & 4 & 0 & 0 & 3 & 9 & 3 & 9 & 2 & 5 \\
\hline CRP land & 1 & 2 & 0 & 5 & 0 & 0 & 1 & 7 & 1 & 7 & 1 & 4 \\
\hline Farm woods & 1 & 2 & 3 & 2 & 1 & 0 & 5 & 4 & 4 & 3 & 3 & 0 \\
\hline Hayfields & 3 & 3 & 3 & 1 & 1 & 0 & 7 & 4 & 7 & 4 & 4 & 2 \\
\hline Cattle & 0 & 1 & 1 & 2 & 0 & 0 & 1 & 3 & 1 & 2 & 0 & 0 \\
\hline Cows & 2 & 2 & 4 & 2 & 1 & 1 & 7 & 5 & 5 & 4 & 2 & 2 \\
\hline Pasture & 2 & 3 & 3 & 1 & 2 & 0 & 7 & 4 & 5 & 3 & 3 & 3 \\
\hline Rangeland & 7 & 1 & 5 & 0 & 1 & 0 & 13 & 1 & 12 & 0 & 5 & 0 \\
\hline Region & 1 & 2 & 0 & 2 & 0 & 1 & 1 & 5 & 1 & 3 & 0 & 2 \\
\hline Harvested crops & 3 & 0 & 3 & 1 & 0 & 0 & 6 & 1 & 6 & 1 & 4 & 0 \\
\hline
\end{tabular}

population trends and CRP fields tended to be negative (Table 5). Numerous species exhibited significant association with changes in number of cows, or the availability of pasturelands, hayfields, and farm woods, but the number of positive and negative correlations was similar (Table 5).

The analyses upon which the preceding summary was based were subject to an increased probability of Type I errors (rejection of a true null hypothesis of no relationship) because they assumed statistical significance at an $\alpha$ of 0.10 (see above). Results (Appendix) were therefore reexamined using the more traditional $\alpha$ of 0.05 as standard for establishing significance. There were no qualitative and nearly no quantitative changes in my conclusions (Table 5). Even more stringent conditions were also applied for establishing significance by applying a Bonferroni correction for multiple tests to my original $\alpha$ of 0.10 (0.10 of 10 comparisons for each species, corrected $\alpha=0.01$ ). Number of species exhibiting significant associations with landscape variables was reduced $(29$ of 63 species $=$ $44.4 \%$ ), but the essential conclusions remained unchanged: changes in bird populations were

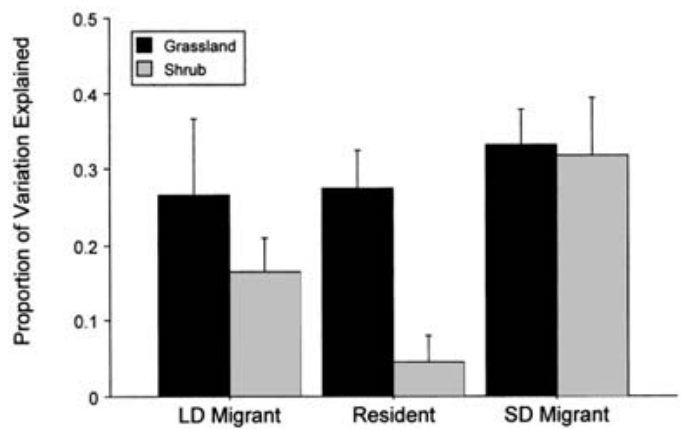

FIG. 3. Comparison between habitat (grassland and shrub) and migrant classes of the mean coefficient of determination $\left(R^{2}\right)$ from analyses of avian population trends in relation to changes in composition of the agricultural landscapes. The height of the bar and the vertical line represent the mean $\pm 1 \mathrm{SE}$, respectively. LD Migrant = long-distance migrant; SD Migrant $=$ short-distance migrant; Resident $=$ year-round resident.

associated with changes of rangeland $(+)$, cover crops (-), harvested cropland (+), and CRP acreage $(-)$ (Table 5).

\section{Discussion}

As predicted, grassland birds showed stronger population declines than did birds from shrub habitats (see also Askins 1993, Knopf 1994, Warner 1994, Vickery et al. 1999, Peterjohn and Sauer 1999). Indeed, 15 of the 25 grassland species exhibited significant negative trends between 1980 and 1999, and the average rate $\left(-1.1 \%\right.$ year $\left.^{-1}\right)$ was significantly less than zero. Many of the shrub species breeding in the same regions at the same time also registered significant declines, but they were not as widespread (13 of 33 species), and the average population trend $\left(-0.26 \%\right.$ year $\left.^{-1}\right)$ did not differ from zero. I hasten to point out that my analyses excluded species with small or rapidly declining populations because they did not provide enough data for quantitative analysis. Some would have been classified as shrub species (e.g. Golden-winged Warblers [Vermivora chrysoptera]; Bell's Vireo [Vireo bellii]), but most are dependent on grasslands (e.g. Henslow's Sparrow [Ammodramus henslowii]; Bachman's Sparrow [Aimophila aestivalis]). I view my results as conservative, yet 60 and $39 \%$ of grassland and shrub species, respectively, exhibited declines between 1980 and 1998. 
The categorization of birds into migratory and nesting groups helped refine our understanding of the relationship between habitat and population trends. For instance, the association of negative population trends with breeding in grasslands existed independently of nesting biology and migratory behavior. The latter is particularly important because it indicates that grassland birds declined regardless of where they overwintered. Similarly, species that place their nests in sheltered sites (niches or cavities), or as exposed, open-cup nests (on the ground or in trees) exhibited no tendency to differ in long-term trends, suggesting that differential exposure to nest predators did not influence population trends (see also Sauer et al. 1996).

The strong association of population declines with breeding in grasslands, regardless of migratory or nesting behavior, suggests strongly that events on the breeding grounds have driven the decline of grassland birds (Askins 1993, Igl and Johnston 1997, Vickery et al. 1999). Most telling perhaps is the finding that five of six grassland-breeding, long-distance migrants declined significantly between 1980 and 1998. Grassland habitats in the wintering regions of those birds are also being lost to agriculture (Vickery et al. 1999), but not all of the grassland-breeding, long-distance migrants overwinter in grasslands (e.g. Eastern Kingbird). Other factors no doubt contribute to the population trends of individual species (e.g. Dickcissels; Basili and Temple 1999), but phenomena in North America appear to have had an overriding influence on the population trends of grassland birds.

Population trends and changes in farmland structure.-Most species exhibited at least one significant correlation between population trends and farmland habitat availability. The ability of farmland structure to account for variation in population trends was independent of nest type, but about a third of the variation in trends of the short-distance migrants was accounted for by changes in the farmland landscape compared to 20 and $13 \%$ for longdistance migrants and residents, respectively. In addition, the average difference in $R^{2}$ between grassland and shrub species (30 vs. $20 \%$ ) was marginally significant. Given that 23 of 25 grassland species, but only 22 of 33 shrub species, exhibited at least one association between population trends and habitat (Fisher's exact test, $P=0.028)$, I am confident in concluding that landscape changes accounted for more of the variability of population trends of birds from grassland than from shrub habitats. Separate analyses of population trends by region (east vs. central states) might have also increased the number of species exhibiting significant associations with landscape variables or may have resulted in higher $R^{2}$ from the regression analyses.

Most grassland species are short-distance migrants that overwinter in agricultural landscapes within North America (Igl and Johnson 1997, Vickery et al. 1999), and it is difficult to cleanly separate short-distance migration from breeding in grasslands. I suggest that the reason why short-distance migrants exhibited the strongest associations with changes in farmland structure is that they were affected by changes in agricultural practices during both the breeding and nonbreeding seasons. Few residents breed in grasslands, and long-distance migrants leave the continent. Hence, it is mainly shortdistance migrants that face year-round exposure to changes in the availability of farmland habitats.

Relative importance of agricultural landscape variables.-It is impossible to ascribe unequivocal cause-and-effect relationships between bird population trends and changes in habitat for at least two reasons. First, analyses did not include some variables that were likely to affect avian numbers (e.g. urban sprawl, increased vehicular traffic, reforestation), and second, landscape variables themselves were often interrelated (Table 2). For instance, Eastern Kingbird population trends were correlated with changes in availability of hayfields $(r=0.395, P=0.000$, $n=38)$, but kingbird population trends also correlated with changes in pasturelands $(r=0.320$, $P=0.05)$. Changes in area of hayfields and pasturelands were likewise positively correlated (Table 2). On the basis of personal experience I am inclined to favor the correlation with pasturelands, but in either case the analyses suggest that the loss of grassland habitat was associated with declines of kingbird populations. Similar problems of interpretation exist with other species, but it is not my purpose to identify habitat features to argue cause-and-effect in individual cases. Rather, my goal is to identify variables that were frequently associated with either increases or decreases of bird populations. 
Regardless of the $\alpha$ used to establish significance, rangeland and cover crops had the most frequent and consistent relationships with avian population trends (Table 5). Based on the intermediate (and traditional) standard for establishing significance $(P<0.05)$, the 12 significant correlations of population trends with rangeland were all positive, and given the negative trend for area of rangeland in states east of the Rocky Mountains (Table 1), that indicates that losses of rangeland were associated with negative population trends for at least 12 species. The importance of rangeland probably stems at least in part from the large proportion of agricultural landscape that it represents $(38.9 \%$ of the land within the sampled agricultural landscape; Table 1), but it also seems likely that rangeland is valuable wildlife habitat because it is the least disturbed of all the habitats listed in Table 1. Rangeland is grazed, but not as heavily as dedicated pasture (U.S. Department of Agriculture 1998), and the lighter grazing pressure may create grasslands with greater horizontal and vertical structural diversity, which on the basis of variable microhabitat needs of grassland birds (Cody 1985, Frawley and Best 1991, Patterson and Best 1996, Delisle and Savidge 1997, Hughes et al. 2000), should support high abundance and diversity of breeding birds (e.g. McMaster and Davis 2001).

The area devoted to cover crop also declined over the study period (Table 1), but 9 of the 12 species that exhibited relationships with cover increased when cover crops declined. Cover crops represented the smallest proportion of the farmland landscape (Table 1), and number of species exhibiting statistically significant associations was surprising. Presumably, the many associations were an outcome of the sharp downward trend of cover crops between 1987 and 1997 (nearly 3\% year ${ }^{-1}$ ), but it may also reflect change in other factors that were not measured but that were correlated with cover crops.

Interestingly, most of the correlations of population trends with changes in CRP lands were negative (seven of eight species). The lone positive correlation, Loggerhead Shrike, is consistent with that species' habitat requirements (Eseley and Bollinger 2001 and references therein). The preponderance of negative correlations stands in contrast to other studies that have shown that many grassland bird species have profited from increases in CRP acreage (Reynolds et al. 1994, Johnson and Igl 1995, Best et al. 1997). However, five of the seven negative associations were with shrub species, and the two negative correlations with grassland species (Common Nighthawk and Vesper Sparrow) were with species that regularly nest in less densely vegetated habitats, including row crops (Rodenhouse and Best 1983, Patterson and Best 1996, Best et al. 1997). The inability to detect positive associations between birds and CRP land possibly stemmed from the relatively small land area encompassed by CRP land (Table 1) and the uneven distribution of CRP land in the United States. The central region of North America is the geographic center for the most grassland dependent species (Vickery et al. 1999), and those same states contain nearly $8 \times$ more CRP land than eastern states (M. T. Murphy unpubl. data). Between 1987 and 1997, CRP land increased in the east at a much higher rate $\left(5.2 \%\right.$ year $\left.^{-1}\right)$ than in the central region $\left(2.3 \%\right.$ year $\left.^{-1}\right)$ due to the fact that eastern states began with almost no CRP land in 1987 (U.S. Department of Agriculture 1998). I suspect therefore that my failure to find positive associations between CRP land and bird populations was due to a mismatch between the areas of large increases in CRP land and the geographic distributions of grassland birds. In addition, as noted for cover crops, it is also possible that environmental variables that were not measured but that correlated with CRP land may have obscured relationships with changes in CRP land area.

Harvested cropland represents a highly diverse set of land uses. Consequently, the interpretation of the significant correlations (six) with that variable is difficult. Croplands seemingly represent poor habitat for most birds, but some birds use row crops either for nesting or foraging (Best et al. 1995, Patterson and Best 1996, McMaster and Davis 2001), and, in four of the six cases in this study, birds may have used harvested land as areas for foraging on either waste grain or possibly rodents that feed upon grain. The surrounding landscape has important influences on the acceptability of cultivated fields as habitat by birds (Best et al. 2001), and that may also account for positive associations of harvested land with population trends of some species.

Finally, number of cows, and the area of pastureland, hayfields, and farm woods were all 
common correlates of avian population change (Table 5). All four were about equally likely to be associated with an increase or decrease in a species. That reflects, presumably, variable habitat needs of different bird species in agricultural landscapes. Surprisingly, changes in number of cattle had few relationships with avian population trends (Table 5), but that may have been because birds responded directly to habitats associated with cattle production rather than cattle themselves (rangeland, pastureland, and hayfields; all correlated with number of cattle at $P \leq 0.05)$.

\section{Conclusion}

Changes in farmland structure have had major effects on breeding birds that use grassland and shrub habitats within agricultural landscapes of the eastern and central United States. Declines in area of rangeland were frequently linked to negative population trends, whereas declines in the area of cover crops were often associated with population increases of other species. All other habitat variables, with the exception of the number of cattle, also exhibited frequent associations with avian population trends. Although changes in area of rangeland seemed to have the most widespread effect on avian populations, the highly individualistic nature of species' habitat needs suggests that a complex habitat mosaic must exist to maintain a diverse avifauna in agricultural landscapes (Best et al. 1990, Warner 1994, Patterson and Best 1996, Shutler et al. 2000). A serious unknown is how nest predators respond to large-scale changes in farmland structure (e.g. Robinson et al. 1995, Donovan et al. 1997; see recent discussion by Heske et al. 2001), and research must address that issue. Issues of nest predators notwithstanding, it is clear that changes in availability of breeding habitats in the United States have had important influences on population trends of grassland birds regardless of whether they are residents or migrants (both short- and long-distance), and although I do not advocate that we ignore the loss of nonbreeding habitat outside of North America, I do argue that much greater attention must be given to conditions on the breeding grounds to ensure long-term viability of populations of grassland birds.

\section{ACKNOWLEDGMENTS}

I am very grateful for the careful readings and suggestions made by A. C. Dolan, K. Kosciuch, N. Lichti, K. L. Murphy, and two anonymous reviewers to earlier versions of the manuscript. Population trend estimates (1980-1999) from the BBS can be accessed online at www.mbr-pwrc.usgs.gov.

\section{Literature Cited}

Askins, R. A. 1993. Population trends of grassland, shrubland, and forest birds in eastern North America. Current Ornithology 11:1-34.

Askins, R. A. 1999. History of grassland birds in eastern North America. Studies in Avian Biology 19:60-71.

Askins, R. A. 2000. Restoring North America's Birds: Lessons from Landscape Ecology. Yale University Press, New Haven, Connecticut.

Askins, R. A. 2001. Sustaining biological diversity in shrub communities: The challenge of managing unpopular habitats. Wildlife Society Bulletin 29:407-412.

Basili, G. D., and S. A. Temple. 1999. Dickcissels and crop damage in Venezuela: Defining the problem with ecological models. Ecological Applications 9:732-739.

Basore, N. S., L. B. Best, and J. B. WoOley, Jr. 1986. Bird nesting in Iowa no-tillage and tilled cropland. Journal of Wildlife Management 50:19-28.

Best, L. B., T. M. Bergin, and K. E. Freemark. 2001. Influence of landscape composition on bird use of rowcrop fields. Journal of Wildlife Management 65:442-449.

Best, L. B., H. Campa III, K. E. Kemp, R. J. Robel, M. R. RYAN, J. A. SAVIDGE, H. P. WeEKS, JR., AND S. R. WINTERSTEIN. 1997. Bird abundance and nesting in CRP fields and cropland in the Midwest: A regional approach. Wildlife Society Bulletin 25:864-877.

Best, L. B., K. E. Freemark, J. J. Dinsmore, and M. CAmp. 1995. A review and synthesis of habitat use by breeding birds in agricultural landscapes of Iowa. American Midland Naturalist 134:1-29.

Best, L. B., R. C. Whitmore, and G. M. Boоth. 1990. Use of cornfields by birds during the breeding season: The importance of edge habitat. American Midland Naturalist 123:84-99.

Bollinger, E. K., P. B. Bollinger, and T. A. Gavin. 1990. Effects of hay-cropping on eastern populations of the Bobolink. Wildlife Society Bulletin 18:142-150.

Cody, M. L. 1985. Habitat selection in grassland and open-country birds. Pages 191-226 in Habitat Selection in Birds (M. L. Cody, Ed.). Academic Press, Orlando, Florida. 
Dale, B. C., P. A. Martin, and P. S. Taylor. 1997. Effects of hay management on grassland songbirds in Saskatchewan. Wildlife Society Bulletin 25:616-626.

DeGraAf, R. M., AND J. H. Rappole. 1995. Neotropical Migratory Birds: Natural History, Distribution, and Population Change. Cornell University Press, Ithaca, New York.

Delisle, J. M., and J. A. Savidge. 1997. Avian use of vegetation characteristics of conservation reserve program fields. Journal of Wildlife Management 61:318-325.

Donovan, T. M., P. W. Jones, E. M. Annand, And F. R. Thompson III. 1997. Variation in local-scale edge effects: Mechanisms and landscape context. Ecology 78:2064-2075.

Ehrlich, P. R., D. S. Dobkin, And D. Wheye. 1988. The Birder's Handbook: A Field Guide to the Natural History of North American Birds. Simon and Schuster, New York.

Esely, J. D., JR., AND E. K. Bollinger. 2001. Habitat selection and reproductive success of Loggerhead Shrikes in northwest Missouri: A hierarchical approach. Wilson Bulletin 113:290-296.

Frawley, B. J., AND L. B. Best. 1991. Effects of mowing on breeding bird abundance and species composition in alfalfa fields. Wildlife Society Bulletin 19:135-142.

Geissler, P. H., And J. R. SAuer. 1990. Topics in route-regression analysis. Pages 54-57 in Survey Designs and Statistical Methods for the Estimation of Avian Population Trends (J. R. Sauer and S. Droege, Eds.). U.S. Department of the Interior, Fish and Wildlife Service, Biological Report, no. 90.

Hagan, J. M., III. 1993. Decline of the Rufous-sided Towhee in the eastern United States. Auk 110: 863-874.

Herkert, J. R. 1997. Bobolink Dolichonyx oryzivorous population decline in agricultural landscapes in the Midwestern USA. Biological Conservation 80:107-112.

Heske, E. J., S. J. Robinson, And J. D. Brawn. 2001. Nest predation and Neotropical migrant songbirds: Piecing together the fragments. Wildlife Society Bulletin 29:52-61.

Hughes, J. P., R. J. Robel, and K. E. Kemp. 2000. Factors influencing Mourning Dove nest success in CRP fields. Journal of Wildlife Management 64:1004-1008.

Hunter, W. C., D. A. Buehler, R. C. Canterbury, J. L. Confer, And P. B. Hamel. 2001. Conservation of disturbance-dependent birds in eastern North America. Wildlife Society Bulletin 29:440-455.

IGL, L. D., AND D. H. JoHnson. 1997. Changes in breeding bird populations in North Dakota: 1967 to 1992-93. Auk 114:74-92.

JoHnson, D. H. 1999. The insignificance of statis- tical significance testing. Journal of Wildlife Management 63:763-772.

JoHnson, D. H. AND L. D. IGL. 1995. Contributions of the Conservation Reserve Program to populations of breeding birds in North Dakota. Wilson Bulletin 107:709-718.

Knopf, F. L. 1994. Avian assemblages on altered grasslands. Studies in Avian Biology 15: 247-257.

Latta, S. C. And M. E. Baltz. 1997. Population limitation in Neotropical migratory birds: Comments on Rappole and McDonald (1994). Auk 114:754-762.

Martin, T. E. 1995. Avian life history evolution in relation to nest sites, nest predation, and food. Ecological Monographs 65:101-127.

McMaster, D. G., And S. K. Davis. 2001. An evaluation of Canada's Permanent Cover Program: Habitat for grassland birds? Journal of Field Ornithology 72:195-210.

Musters, C. J. M., M. KruK, H. J. De GraAf, And W. J. Ter Keurs. 2000. Breeding birds as a farm product. Conservation Biology 15:363-369.

O'Connor, R. J., AND R. BoOne. 1992. A retrospective study of agricultural bird populations in North America. Ecological Indicators 2:1165-1184.

Patterson, M. P., And L. B. Best. 1996. Bird abundance and nesting success in Iowa CRP fields: The importance of vegetation structure and composition. American Midland Naturalist 135:153-167.

Peterjohn, B. G., and J. R. Sauer. 1999. Population status of North American grassland birds from the North American Breeding Bird Survey, 1966-1996. Studies in Avian Biology 19:27-44.

Rappole, J. H., And M. V. McDonald. 1994. Cause and effect in population declines of migratory birds. Auk 111:652-660.

Rappole, J. H., and M. V. McDonald. 1998. Response to Latta and Baltz (1997). Auk 115: 246-251.

Reynolds, R. E., T. L. Shaffer, J. R. SAuer, And B. G. Peterjohn. 1994. Conservation Reserve Program: Benefit for grassland birds in the northern plains. Transactions of the North American Wildlife and Natural Resources Conference 59: 328-336.

Robbins, C. S., D. Bystrak, and P. H. Geissler. 1986. The Breeding Bird Survey: Its first fifteen years, 1965-1979. U.S. Department of the Interior, Fish and Wildlife Service, Resource Publication, no. 157.

Robertson, R. J., B. J. Stutchbury, and R. R. Cohen. 1992. Tree Swallow (Tachycineta bicolor). In The Birds of North America, no. 11 (A. Poole, P. Stettenheim, and F. Gill, Eds.). Academy of Natural Sciences, Philadelphia, and American Ornithologists' Union, Washington, DC. 
Robinson, S. K., F. R. Thompson III, T. M. Donovan, D. R. Whitehead, And J. FAaborg. 1995. Regional forest fragmentation and the nesting success of birds. Science 267:1987-1990.

Rodenhouse, N. L., And L. B. Best. 1983. Breeding ecology of Vesper Sparrows in corn and soybean fields. American Midland Naturalist 110: 265-275.

Rodenhouse, N. L., L. B. Best, R. J. O'Connor, And E. K. Bollinger. 1995. Effects of agricultural practices and farmland structure. Pages 269-293 in Ecology and Management of Neotropical Migratory Birds (T. E. Martin and D. M. Finch, Eds.), Oxford University Press, New York.

Sauer, J. R., G. W. Pendleton, and B. G. Peterjohn. 1996. Evaluating causes of population change in North American insectivorous songbirds. Conservation Biology 10:465-478.

Steidl, R. J., J. P. Hayes, and E. Schauber. 1997. Statistical power analysis in wildlife research. Journal of Wildlife Management 61:270-279.

Sherry, T. W., AND R. T. Holmes. 1995. Summer versus winter limitation of populations: What are the issues and what is the evidence? Pages
85-120 in Ecology and Management of Neotropical Migratory Birds (T. E. Martin and D. M. Finch, Eds.). Oxford University Press, New York.

Shutler, D., A. Mullie, and R. G. Clark. 2000. Bird communities of prairie uplands and wetlands in relation to farming practices in Saskatchewan. Conservation Biology 14:1441-1451.

SAS Institute. 1999. STATVIEW. SAS Institute, Inc., Cary, North Carolina.

U.S. Department of Agriculture. 1998. Agricultural Statistics. U.S. Department of Agriculture, Washington, D.C.

Vickery, P. D., P. L. Tubaro, J. M. Cardoso da Silva, B. G. Peterjohn, J. R. Herkert, and R. B. CavALCANTI. 1999. Conservation of grassland birds in the Western Hemisphere. Studies in Avian Biology 19:2-26.

WArner, R. E. 1994. Agricultural land use and grassland habitat in Illinois: Future shock for Midwestern birds. Conservation Biology 8: 147-156.

Associate Editor: F. Moore

APPENDIX. Summary of habitat $(\mathrm{H})$, migratory $(\mathrm{M})$, and nesting $(\mathrm{N})$ classifications for all species, along with BBS trend estimates ("Trend") for the combined eastern and central regions (1980-1999). The coefficient of determination $\left(R^{2}\right)$, significance level $(P)$, and sample size $(N=$ number of states) are listed from the multiple regression relating population trends to agricultural landscape variables. Variables listed under "Significant contributors" accounted for a significant portion of the interstate variation in population trends. The absence of variables indicates that population trends were not able to be associated with any of the variables included in the analyses. The "+" or "-" symbol and the number in the parentheses following each significant contributor describes the nature of its relationship with avian population trends and its significance, respectively.

\begin{tabular}{|c|c|c|c|c|c|c|c|}
\hline Species & $\mathrm{H}$ & $\mathrm{M}$ & $\mathrm{N}$ & Trend & $R^{2}(P)$ & $N$ & Significant contributors \\
\hline $\begin{array}{l}\text { Northern Harrier } \\
\text { (Circus cyaneus) }\end{array}$ & 1 & 2 & 1 & $-0.27(0.765)$ & $0.250(0.081)$ & 10 & Rangeland (-;0.081) \\
\hline $\begin{array}{l}\text { Red-tailed Hawk } \\
\text { (Buteo jamaicensis) }\end{array}$ & 2 & 1 & 2 & $3.49(0.000)$ & $0.171(0.018)$ & 36 & $\begin{array}{l}\text { Number of cows }(-; 0.008) \\
\text { harvested crops }(+, 0.053)\end{array}$ \\
\hline $\begin{array}{l}\text { American Kestrel } \\
\text { (Falco sparverius) }\end{array}$ & 1 & 2 & 3 & $-0.85(0.137)$ & $0.366(0.001)$ & 31 & $\begin{array}{l}\text { Rangeland }(+; 0.000) \text {, cover crops } \\
(-; 0.008)\end{array}$ \\
\hline $\begin{array}{l}\text { Northern Bobwhite } \\
\text { (Colinus virginianus) }\end{array}$ & 1 & 1 & 1 & $-3.75(0.000)$ & $0.329(0.001)$ & 28 & Harvested crops $(+; 0.001)$ \\
\hline $\begin{array}{l}\text { Ring-necked Pheasant } \\
\text { (Phasianus colchicus) }\end{array}$ & 1 & 1 & 1 & $-0.76(0.115)$ & $0.321(0.008)$ & 23 & $\begin{array}{l}\text { Harvested crops }(+; 0.012) \text {, pasture } \\
(+; 0.027)\end{array}$ \\
\hline $\begin{array}{l}\text { Turkey Vulture } \\
\text { (Cathartes aura) }\end{array}$ & 1 & 2 & 1 & $1.55(0.005)$ & $0.130(0.040)$ & 26 & Cows $(-; 0.040)$ \\
\hline $\begin{array}{l}\text { Killdeer } \\
\text { (Charadrius vociferous) }\end{array}$ & 1 & 2 & 1 & $-0.26(0.283)$ & $0.111(0.022)$ & 39 & Cover crops $(-; 0.022)$ \\
\hline $\begin{array}{l}\text { Upland Sandpiper } \\
\text { (Bartramia longicauda) }\end{array}$ & 1 & 3 & 1 & $-1.43(0.017)$ & - & 10 & \\
\hline $\begin{array}{l}\text { Wilson's Snipe } \\
\text { (Gallinago delicata) }\end{array}$ & 1 & 2 & 1 & $-1.43(0.043)$ & $0.473(0.044)$ & 10 & $\begin{array}{l}\text { Hayfields }(+; 0.016) \text {, cover crops } \\
(-; 0.033)\end{array}$ \\
\hline $\begin{array}{l}\text { Mourning Dove } \\
\text { (Zenaida macroura) }\end{array}$ & 1 & 1 & 2 & $-0.35(0.022)$ & $0.172(0.023)$ & 39 & Pasture $(-; 0.066)$, region $(-; 0.077)$ \\
\hline $\begin{array}{l}\text { Yellow-billed Cuckoo } \\
\text { (Coccyzus americanus) }\end{array}$ & 2 & 3 & 2 & $-2.96(0.000)$ & $0.152(0.021)$ & 29 & Farm woods $(+; 0.021)$ \\
\hline $\begin{array}{l}\text { Black-billed Cuckoo } \\
\text { (C. erythropthalmus) }\end{array}$ & 2 & 3 & 2 & $-2.71(0.000)$ & $0.423(0.002)$ & 22 & $\begin{array}{l}\text { Harvested crops }(+; 0.003) \text {, number } \\
\text { of cattle }(+; 0.038)\end{array}$ \\
\hline
\end{tabular}


APPENDIX. Continued.

\begin{tabular}{|c|c|c|c|c|c|c|c|}
\hline Species & $\mathrm{H}$ & $\mathrm{M}$ & $\mathrm{N}$ & Trend & $R^{2}(P)$ & $N$ & Significant contributors \\
\hline $\begin{array}{l}\text { Common Nighthawk } \\
\text { (Chordeiles minor) }\end{array}$ & 1 & 3 & 1 & $-3.87(0.000)$ & $0.553(0.001)$ & 21 & $\begin{array}{l}\text { Hayfields }(-; 0.000), \text { CRP land } \\
(-; 0.044), \text { number of cows } \\
(+; 0.066)\end{array}$ \\
\hline $\begin{array}{l}\text { Red-headed Woodpecker } \\
\text { (Melanerpes erythrocephalus }\end{array}$ & & 2 & 3 & $-4.63(0.000)$ & $0.180(0.039)$ & 26 & $\begin{array}{l}\text { Harvested crops }(-; 0.018) \text {, number } \\
\text { of cows }(+0.060)\end{array}$ \\
\hline $\begin{array}{l}\text { Northern Flicker } \\
\text { (Colaptes auratus) }\end{array}$ & 2 & 2 & 3 & $-2.50(0.000)$ & - & 39 & \\
\hline $\begin{array}{l}\text { Eastern Phoebe } \\
\text { (Sayornis phoebe) }\end{array}$ & 2 & 2 & 3 & $2.61(0.000)$ & $0.318(0.004)$ & 31 & $\begin{array}{l}\text { Farm woods }(+; 0.010) \text {, number of } \\
\text { cows }(+; 0.028), \text { number of cattle } \\
(-; 0.062)\end{array}$ \\
\hline $\begin{array}{l}\text { Willow Flycatcher } \\
\text { (Empidonax traillii) }\end{array}$ & 2 & 3 & 2 & $-0.03(0.820)$ & $0.335(0.015)$ & 20 & $\begin{array}{l}\text { Pasture }(-; 0.004), \text { rangeland } \\
(+; 0.047)\end{array}$ \\
\hline $\begin{array}{l}\text { Eastern Kingbird } \\
\text { (Tyrannus tyrannus) }\end{array}$ & 1 & 3 & 2 & $-1.78(0.000)$ & $0.154(0.015)$ & 38 & Hayfields $(+; 0.015)$ \\
\hline $\begin{array}{l}\text { Loggerhead Shrike } \\
\text { (Lanius ludovicianus) }\end{array}$ & 1 & 2 & 2 & $-2.24(0.000)$ & $0.249(0.030)$ & 21 & $\begin{array}{l}\text { Cover crops }(+; 0.001), \text { CRP land } \\
(+; 0.002)\end{array}$ \\
\hline $\begin{array}{l}\text { White-eyed Vireo } \\
\text { (Vireo griseus) }\end{array}$ & 2 & 3 & 2 & $0.22(0.376)$ & $0.548(0.000)$ & 23 & $\begin{array}{l}\text { Number of cows }(+; 0.000) \text {, hay- } \\
\text { fields }(+; 0.005)\end{array}$ \\
\hline $\begin{array}{l}\text { American Crow } \\
\text { (Corvus brachyrhynchos) }\end{array}$ & 2 & 1 & 2 & $1.60(0.000)$ & $0.059(0.077)$ & 38 & Farm woods $(-; 0.077)$ \\
\hline $\begin{array}{l}\text { Horned Lark } \\
\text { (Eremophila alpestris) }\end{array}$ & 1 & 2 & 1 & $-2.39(0.000)$ & $0.251(0.014)$ & 26 & $\begin{array}{l}\text { Cover crops }(-; 0.010), \text { rangeland } \\
(+; 0.032)\end{array}$ \\
\hline $\begin{array}{l}\text { Purple Martin } \\
\text { (Progne subis) }\end{array}$ & 3 & 3 & 3 & $-1.47(0.001)$ & $0.413(0.001)$ & 30 & $\begin{array}{l}\text { Hayfields }(+; 0.001), \text { region } \\
(-; 0.003) \text {, rangeland }(+; 0.031), \\
\text { farm woods }(+; 0.080)\end{array}$ \\
\hline $\begin{array}{l}\text { Northern Rough-winged } \\
\text { Swallow } \\
\text { (Stelgidopteryx serripennis) }\end{array}$ & 3 & 3 & 3 & $-0.15(0.827)$ & - & 29 & \\
\hline $\begin{array}{l}\text { Bank Swallow } \\
\text { (Riparia riparia) }\end{array}$ & 3 & 3 & 3 & $-4.46(0.001)$ & $0.478(0.012)$ & 16 & $\begin{array}{l}\text { Pasture }(+; 0.008) \text {, number of cows } \\
(+; 0.029) \text {, farm woods }(+; 0.080)\end{array}$ \\
\hline $\begin{array}{l}\text { Tree Swallow } \\
\text { (Tachycineta bicolor) }\end{array}$ & 2 & 3 & 3 & $-0.85(0.051)$ & $0.259(0.015)$ & 19 & Farm woods $(-; 0.015)$ \\
\hline $\begin{array}{l}\text { Cliff Swallow } \\
\text { (Petrochelidon pyrrhonota) }\end{array}$ & 3 & 3 & 3 & $0.34(0.707)$ & $0.123(0.084)$ & 18 & Number of cows $(-; 0.084)$ \\
\hline $\begin{array}{l}\text { Barn Swallow } \\
\text { (Hirundo rustica) }\end{array}$ & 3 & 3 & 3 & $-1.76(0.001)$ & $0.058(0.082)$ & 37 & Pasture $(+; 0.082)$ \\
\hline $\begin{array}{l}\text { Carolina Wren } \\
\text { (Thryothorus ludovicianus) }\end{array}$ & 2 & 1 & 3 & $1.67(0.001)$ & 一 & 23 & \\
\hline $\begin{array}{l}\text { House Wren } \\
\text { (Troglodytes aedon) }\end{array}$ & 2 & 2 & 3 & $1.34(0.001)$ & $0.735(0.000)$ & 31 & $\begin{array}{l}\text { Pasture }(+; 0.000), \text { CRP land } \\
(-; 0.010), \text { rangeland }(+; 0.016), \\
\text { cover crops }(-; 0.044)\end{array}$ \\
\hline $\begin{array}{l}\text { Sedge Wren } \\
\text { (Cistothorus platensis) }\end{array}$ & 1 & 2 & 1 & $2.57(0.006)$ & $0.741(0.017)$ & 6 & Number of cattle $(-; 0.017)$ \\
\hline $\begin{array}{l}\text { Eastern Bluebird } \\
\text { (Sialia sialis) }\end{array}$ & 1 & 2 & 3 & $3.33(0.000)$ & $0.206(0.012)$ & 33 & $\begin{array}{l}\text { Hayfields }(-; 0.006) \text {, rangeland } \\
(+; 0.051)\end{array}$ \\
\hline $\begin{array}{l}\text { American Robin } \\
\text { (Turdus migratorius) }\end{array}$ & 2 & 2 & 2 & $0.78(0.000)$ & $0.345(0.001)$ & 39 & $\begin{array}{l}\text { Rangeland }(+; 0.006) \text {, cover crops } \\
(-; 0.006) \text {, region }(-; 0.033)\end{array}$ \\
\hline $\begin{array}{l}\text { Gray Catbird } \\
\text { (Dumetella carolinensis) }\end{array}$ & 2 & 3 & 2 & $-0.16(0.399)$ & - & 39 & \\
\hline $\begin{array}{l}\text { Northern Mockingbird } \\
\text { (Mimus polyglottos) }\end{array}$ & 2 & 1 & 2 & $-0.05(0.809)$ & - & 31 & \\
\hline $\begin{array}{l}\text { Brown Thrasher } \\
\text { (Toxostoma rufum) }\end{array}$ & 2 & 2 & 2 & $-1.14(0.000)$ & $0.093(0.039)$ & 36 & Pasture $(+; 0.039)$ \\
\hline $\begin{array}{l}\text { Cedar Waxwing } \\
\text { (Bombycilla cedrorum) }\end{array}$ & 2 & 2 & 2 & $-0.13(0.700)$ & $0.907(0.000)$ & 22 & $\begin{array}{l}\text { Number of cows }(-; 0.000) \text {, } \\
\text { rangeland }(+; 0.000), \text { CRP land } \\
(-; 0.001) \text {, region }(-; 0.011)\end{array}$ \\
\hline $\begin{array}{l}\text { Blue-winged Warbler } \\
\text { (Vermivora pinus) }\end{array}$ & 2 & 3 & 2 & $0.16(0.810)$ & - & 13 & \\
\hline $\begin{array}{l}\text { Yellow Warbler } \\
\text { (Dendroica petechia) }\end{array}$ & 2 & 3 & 2 & $0.83(0.006)$ & - & 29 & \\
\hline $\begin{array}{l}\text { Chestnut-sided Warbler } \\
\text { (D. pensylvanica) }\end{array}$ & 2 & 3 & 2 & $-0.35(0.366)$ & - & 13 & \\
\hline
\end{tabular}


APPENDIX. Continued.

\begin{tabular}{|c|c|c|c|c|c|c|c|}
\hline Species & $\mathrm{H}$ & $\mathrm{M}$ & $\mathrm{N}$ & Trend & $R^{2}(P)$ & $N$ & Significant contributors \\
\hline $\begin{array}{l}\text { Prairie Warbler } \\
\text { (D. discolor) }\end{array}$ & 2 & 3 & 2 & $-0.86(0.060)$ & - & 20 & \\
\hline $\begin{array}{l}\text { Common Yellowthroat } \\
\text { (Geothlypis trichas) }\end{array}$ & 1 & 3 & 2 & $-0.74(0.000)$ & $0.491(0.000)$ & 38 & $\begin{array}{l}\text { Number of cows }(+; 0.000) \text {, cover } \\
\text { crops }(+; 0.017) \text {, farm woods } \\
(-; 0.036), \text { rangeland }(+; 0.049), \\
\text { pasture }(+; 0.089)\end{array}$ \\
\hline $\begin{array}{l}\text { Yellow-breasted Chat } \\
\text { (Icteria virens) }\end{array}$ & 2 & 3 & 2 & $0.62(0.020)$ & $0.128(0.041)$ & 26 & Hayfields $(+; 0.041)$ \\
\hline $\begin{array}{l}\text { Northern Cardinal } \\
\text { (Cardinalis cardinalis) }\end{array}$ & 2 & 1 & 2 & $0.56(0.000)$ & - & 33 & \\
\hline $\begin{array}{l}\text { Blue Grosbeak } \\
\text { (Guiraca caerulea) }\end{array}$ & 2 & 3 & 2 & $0.22(0.509)$ & $0.136(0.051)$ & 22 & CRP land $(-; 0.051)$ \\
\hline $\begin{array}{l}\text { Indigo Bunting } \\
\text { (Passerina cyanea) }\end{array}$ & 2 & 3 & 2 & $-0.94(0.000)$ & $0.315(0.001)$ & 33 & $\begin{array}{l}\text { Hayfields }(+; 0.001) \text {, number of } \\
\text { cows }(+; 0.027)\end{array}$ \\
\hline $\begin{array}{l}\text { Dickcissel } \\
\text { (Spiza americana) }\end{array}$ & 1 & 3 & 1 & $0.10(0.756)$ & - & 19 & \\
\hline $\begin{array}{l}\text { Eastern Towhee } \\
\text { (Pipilo erythrophthalmus) }\end{array}$ & 2 & 2 & 1 & $-0.93(0.000)$ & $0.462(0.000)$ & 30 & $\begin{array}{l}\text { Pasture }(+; 0.000), \text { cover crops } \\
(-; 0.024)\end{array}$ \\
\hline $\begin{array}{l}\text { Field Sparrow } \\
\text { (Spizella pusilla) }\end{array}$ & 2 & 2 & 1 & $-2.32(0.000)$ & $0.244(0.006)$ & 33 & $\begin{array}{l}\text { CRP land }(-; 0.050) \text {, rangeland } \\
(+; 0.064)\end{array}$ \\
\hline $\begin{array}{l}\text { Chipping Sparrow } \\
\text { (S. passerina) }\end{array}$ & 2 & 2 & 2 & $0.50(0.006)$ & $0.234(0.002)$ & 36 & Cover crops $(-; 0.002)$ \\
\hline $\begin{array}{l}\text { Grasshopper Sparrow } \\
\text { (Ammodramus savannarum) }\end{array}$ & 1 & 2 & 1 & $-2.39(0.000)$ & $0.127(0.038)$ & 27 & Rangeland $(+; 0.038)$ \\
\hline $\begin{array}{l}\text { Savannah Sparrow } \\
\text { (Passerculus sandwichensis) }\end{array}$ & 1 & 2 & 1 & $-0.20(0.540)$ & $0.682(0.001)$ & 16 & $\begin{array}{l}\text { Cover crops }(+; 0.000) \text {, harvested } \\
\text { crops }(+; 0.009), \text { farm woods } \\
(-; 0.035)\end{array}$ \\
\hline $\begin{array}{l}\text { Vesper Sparrow } \\
\text { (Pooecetes gramineus) }\end{array}$ & 1 & 2 & 1 & $-0.62(0.289)$ & $0.433(0.001)$ & 21 & CRP land $(-; 0.001)$ \\
\hline $\begin{array}{l}\text { Lark Sparrow } \\
\text { (Chondestes grammacus) }\end{array}$ & 1 & 2 & 1 & $-2.90(0.000)$ & $0.282(0.044)$ & 12 & Number of cows $(-; 0.044)$, \\
\hline $\begin{array}{l}\text { Song Sparrow } \\
\text { (Melospiza melodia) }\end{array}$ & 2 & 2 & 1 & $0.41(0.010)$ & $0.503(0.000)$ & 27 & $\begin{array}{l}\text { CRP land }(-; 0.000), \text { farm woods } \\
(+; 0.010) \text {, Harvested crops }(+; 0.018)\end{array}$ \\
\hline $\begin{array}{l}\text { Eastern Meadowlark } \\
\text { (Sturnella magna) }\end{array}$ & 1 & 2 & 1 & $-3.11(0.000)$ & $0.302(0.004)$ & 32 & $\begin{array}{l}\text { Cover crops }(-; 0.003), \text { farm woods } \\
(+; 0.008) \text {, region }(+; 0.035)\end{array}$ \\
\hline $\begin{array}{l}\text { Bobolink } \\
\text { (Dolichonyx oryzivorus) }\end{array}$ & 1 & 3 & 1 & $-3.25(0.000)$ & $0.395(0.007)$ & 22 & $\begin{array}{l}\text { Hayfields }(+; 0.004), \text { pasture } \\
(-; 0.010) \text {, region }(+; 0.070)\end{array}$ \\
\hline $\begin{array}{l}\text { Brown-headed Cowbird } \\
\text { (Molothrus ater) }\end{array}$ & 1 & 2 & 4 & $-0.96(0.000)$ & $0.218(0.003)$ & 39 & $\begin{array}{l}\text { Hayfields }(-; 0.006), \text { rangeland } \\
(+; 0.007)\end{array}$ \\
\hline $\begin{array}{l}\text { Red-winged Blackbird } \\
\text { (Agelaius phoeniceus) }\end{array}$ & 1 & 2 & 1 & $-0.97(0.000)$ & $0.358(0.000)$ & 39 & $\begin{array}{l}\text { Rangeland }(+; 0.000), \text { pasture } \\
(-; 0.005)\end{array}$ \\
\hline $\begin{array}{l}\text { Common Grackle } \\
\text { (Quiscalus quiscula) }\end{array}$ & 2 & 2 & 2 & $-1.70(0.000)$ & $0.107(0.029)$ & 36 & Number of cattle $(-; 0.029)$ \\
\hline $\begin{array}{l}\text { Baltimore Oriole } \\
\text { (Icterus galbula) }\end{array}$ & 2 & 3 & 2 & $-1.45(0.000)$ & - & 29 & \\
\hline $\begin{array}{l}\text { Orchard Oriole } \\
\text { (I. spurius) }\end{array}$ & 2 & 3 & 2 & $-0.73(0.044)$ & $0.165(0.018)$ & 28 & Hayfields (-; 0.018) \\
\hline $\begin{array}{l}\text { American Goldfinch } \\
\text { (Carduelis tristis) }\end{array}$ & 2 & 2 & 1 & $0.94(0.000)$ & - & 35 & \\
\hline
\end{tabular}

$\mathrm{H}=$ habitat ( 1 = grassland; 2 = shrub; 3 = aerial); $\mathrm{M}=$ migrant class $(1$ = resident; 2 = short-distance migrant; $3=$ long-distance migrant); $\mathrm{N}=$ nesting habitat $(1=$ open-cup nest on or $\leq 1 \mathrm{~m}$ above ground; $2=$ open-cup nest $>1 \mathrm{~m}$ above ground; $3=$ niche- and cavity-nesting species, $4=$ interspecific brood parasite). 